\title{
Endotoxin-induced Pulmonary Dysfunction Is Prevented by C1-Esterase Inhibitor
}

\author{
Rafael Guerrero, Francisco Velasco, Mariano Rodriguez, Antonio Lopez, * Rafael Rojas, Miguel A. Alvarez, Rafael Villalba, \\ Vicente Rubio, Antonio Torres, and Domingo del Castillo \\ Unidad de Investigación, Servicios de Cuidados Intensivos, Hematología y Nefrología, Hospital Universitario Reina Sofia, and \\ * Departamento de Bioquímica y Biología Molecular, Universidad de Córdoba, 14004 Córdoba Spain
}

\begin{abstract}
In septic shock, hypotension, disseminated intravascular coagulation, and neutrophil activation are related to the activation of the blood coagulation contact system. This study evaluates in dogs the effect of the C1-esterase inhibitor (C1-INH), a main inhibitor of the blood coagulation contact system, on the cardiovascular and respiratory dysfunction associated with endotoxic shock. Two groups were included: controls, which received Escherichia coli endotoxin, and a C1-INH group in which C1INH was infused before $E$. coli endotoxin administration.

In both groups, endotoxin produced hypodynamic shock; however, the decrease in the systolic index and the ventricular systolic work indexes were greater in controls than the C1-INH group. In controls, the arterial $\mathrm{O}_{2}$ partial pressure decreased by $30 \%$ and the alveolo-arterial $\mathrm{O}_{2}$ difference increased by $625 \%$, these parameters remained unchanged in the C1-INH group. Hypoxemia was associated with increased intrapulmonary shunt, decreased blood coagulation contact factors, and decreased C3c. In contrast, C1-INH administration prevented endotoxin-induced hypoxemia, the increase in intrapulmonary shunt, and the decrease in blood coagulation contact factors.

This study shows that, in dogs with endotoxic shock, pulmonary dysfunction is associated with an activation of the blood coagulation contact phase system. An inhibition of this system by C1-INH prevented the hypoxemia induced by endotoxic shock. (J. Clin. Invest. 1993.91:2754-2760.) Key words: acute respiratory distress syndrome $\bullet \mathrm{Cl}$-esterase inhibitor • coagulation • endotoxins $\bullet$ hypoxemia
\end{abstract}

\section{Introduction}

Gram-negative bacteriemia produces multiorgan dysfunction, septic shock, and frequently death (1-7). The pathogenic factors and mechanisms involved in septic shock are still unclear.

Endotoxin may directly impair the cardiac function. Several authors have observed that the intravenous administration of endotoxin produces a deterioration of cardiac function; this negative effect is independent of cardiac filling pressure and systemic vascular resistance (8-12).

In addition, endotoxin may induce multiorgan dysfunction by an activation of the coagulation pathways at multiple sites.

Address reprint requests to Dr. Rafael Guerrero, Unidad de Cuidados Intensivos, Hopital Universitario Reina Sofia, Avda. Menendez Pidal S/N, 14004 Córdoba, Spain.

Received for publication 26 April 1992 and in revised form 31 December 1992.

J. Clin. Invest.

(c) The American Society for Clinical Investigation, Inc.

0021-9738/93/06/2754/07 \$2.00

Volume 91, June 1993, 2754-2760
Endotoxemia increases plasma protease activity (13-17) and promotes the activation of the blood contact system contributing to disseminated intravascular coagulation, hypotension, and neutrophil activation (18). It appears that endotoxin activates the coagulation through both a direct effect and by influencing endothelial cell function (19-22). Pulmonary dysfunction due to acute respiratory distress syndrome (ARDS) ${ }^{1}$ occurs in $25-40 \%$ of patients with endotoxemia $(23,24)$. Microscopic examination of lung tissues from ARDS patients shows damage in both alveolar epithelial cells and capillary endothelium. This is accompanied by a hemorrhagic intraalveolar exudate high in platelets, fibrin clotting factors, and plasminogen $(25,26)$. Recently, Idell et al. (27) have documented that both tissue factor VII procoagulant activity and extrinsic pathway inhibitor activity were increased in bronchoalveolar lavage of ARDS patients. In addition, Bertozzi et al. (28) have shown an increase in antifibrinolytic activity in the bronchoalveolar lavage of patients with ARDS. These studies suggest that an alteration in blood coagulation and fibrinolysis may play a role in the pathogenesis of ARDS induced by endotoxemia.

In a previous report, we observed decreased plasma levels of prekallikrein (PK) in patients with ARDS (29); this finding was considered a result of the activation of the contact phase of blood coagulation $(29,30)$. In these patients, the decrease in plasma PK levels correlated with the degree of pulmonary dysfunction. By contrast, plasma PK levels were unchanged in patients with cardiogenic pulmonary edema which is not associated with structural pulmonary damage (31). Taken together these results suggest that an activation of the blood coagulation contact system could be a factor in the pathogenesis of endotoxin-induced ARDS.

C1-esterase inhibitor (C1-INH) is the main inhibitor of the blood coagulation contact system $(32,33)$. In that hypotension, disseminated intravascular coagulation and neutrophil activation are consequences of activation of the contact system, its inhibition by administration of C1-INH may help to prevent endotoxin-induced organ dysfunction $(22,34,35)$.

\footnotetext{
1. Abbreviations used in this paper: AP, arterial pressure; ARDS, acute respiratory distress syndrome; $\mathrm{A}-\mathrm{aDcO}_{2}$, alveolo-arterial $\mathrm{O}_{2}$ difference; a-vDcO ${ }_{2}$, arterio-venous $\mathrm{O}_{2}$ difference; $\mathrm{Cl}$ - $\mathrm{INH}, \mathrm{Cl}$-esterase inhibitor; $\mathrm{CI}$, cardiac index; $\mathrm{CO}$, cardiac output; $\mathrm{CVP}$, central venous pressure; HR, heart rate; LVSWI, left ventricular systolic work index; MAP, mean arterial pressure; MPAP, mean pulmonary arterial pressure; $\mathrm{O}_{2-}$ Deliv, $\mathrm{O}_{2}$ delivery; $\mathrm{PaCO}_{2}$, arterial $\mathrm{CO}_{2}$ partial pressure; $\mathrm{PaO}_{2}$, arterial $\mathrm{O}_{2}$ partial pressure; PCWP, pulmonary capillary wedge pressure; $\mathrm{PK}$, prekallikrein; $\mathrm{PvO}_{2}$, mixed venous blood $\mathrm{O}_{2}$ partial pressure; PVRI, pulmonary vascular resistance index; Qs/Qt\%, intrapulmonary shunt; RVSWI, right ventricular stroke work index; $\mathrm{SATaO}_{2}$, arterial $\mathrm{O}_{2}$ saturation; $\mathrm{SATVO}_{2}$, mixed venous blood $\mathrm{O}_{2}$ saturation; $\mathrm{SI}$, systolic index; SVRI, systemic vascular resistance index; $\mathrm{VO}_{2}, \mathrm{O}_{2}$ consumption.
} 
The aim of this study was to evaluate the effect of inhibition of the blood coagulation contact system on the cardiovascular and respiratory function in an animal model of endotoxic shock.

\section{Methods}

Animal model. The study was performed in mongrel dogs (22-32 kg). During the 24-h period before the experiment, the dogs were allowed access to water but not food. $1 \mathrm{~h}$ before the initiation of the study, the dogs received droperidol $(2.5 \mathrm{mg})$ and fentanyl $(0.05 \mathrm{mg})$ intramuscularly. Anesthesia was induced by i.v. administration of sodium pentobarbital ( $15 \mathrm{mg} / \mathrm{kg}$ of body weight $)$, pancuronium bromide $(0.1 \mathrm{mg} /$ $\mathrm{kg}$ of body weight), and fentanyl $(0.05 \mathrm{mg} / \mathrm{kg}$ of body weight $)$. An endotracheal tube was placed and ventilation was maintained using a volumetric respirator (Pulmelec, Manofacturas Medicas, Madrid, Spain). The ventilatory parameters were: tidal volume $15 \mathrm{ml} / \mathrm{kg}$ of body weight; fraction of inspired oxygen $\left(\mathrm{FiO}_{2}\right)=0.5$ mixed with nitrogenous-protoxide $\left(\mathrm{N}_{2} \mathrm{O}_{2}\right)$; pulmonary end-expiratory pressure (PEEP) $=5 \mathrm{~cm} \mathrm{H} \mathrm{H}_{2} \mathrm{O}$; respiratory rate between 12 and $15 \mathrm{rpm}$ maintaining the partial pressure of arterial carbon dioxide $\left(\mathrm{PaCO}_{2}\right)$ at $32-35$ $\mathrm{mm} \mathrm{Hg}$.

An indwelling catheter was inserted into the femoral artery for blood pressure monitoring and blood sampling. A triple-lumen thermodilution Swan-Ganz catheter (Edwards Laboratories AHS, Añasco, Puerto Rico) was introduced through an upper limb vein and advanced into a main pulmonary artery. Both the Swan-Ganz and the arterial catheters were connected to pressure transducers (model 21080A, Hewlett-Packard Co., Palo Alto, CA) previously leveled with the right atrium. Pressure measurements and electrocardiogram were recorded using a four-channel amplifier (model 7754B, Hewlett Packard Co.).

Cardiac output (CO) was measured by the thermodilution technique (cardiac output computer model 9520 , Edwards Laboratories); each value was the mean of three consecutive determinations.

Study protocol. The dogs were divided into two groups: $(a)$ a control group $(n=8)$, in which Escherichia coli endotoxin $(2 \mathrm{mg} / \mathrm{kg})$ was infused intravenously during a 10-min period, (E. coli acetone powder, serotype 026:B6 strain ATCC 12795, Sigma Chemical Co., St Louis, USA); $(b)$ an experimental group $(n=8)$, which received $E$. coli endotoxin as in the control group and an i.v. injection of the contact system inhibitor, C1-INH ( 500 IU) (Behring Institute, Marburg, FRG). The $\mathrm{Cl}$-INH was administered $30 \mathrm{~min}$ before the infusion of $E$. coli endotoxin.

The following hemodynamic parameters were measured immediately before and at 60,120 , and $180 \mathrm{~min}$ after the administration of the endotoxin: arterial pressure (AP), heart rate (HR), pulmonary arterial pressure (PAP), central venous pressure (CVP), pulmonary capillary wedge pressure (PCWP), $\mathrm{CO}$, partial pressure of arterial oxygen $\mathrm{PaO}_{2}$, $\mathrm{PaCO}_{2}$, partial pressure of mixed venous blood oxygen $\left(\mathrm{PvO}_{2}\right)$, arterial oxygen saturation $\left(\mathrm{SATaO}_{2}\right)$, mixed venous blood oxygen saturation $\left(\mathrm{SATvO}_{2}\right)$, and hemoglobin.

The following hemodynamic and pulmonary function parameters were calculated based on previously published formulas $(36,37)$ : mean arterial pressure (MAP), mean pulmonary arterial pressure (MPAP), cardiac index (CI), systolic index (SI), left ventricular systolic work index (LVSWI), right ventricular systolic work index (RVSWI), systemic vascular resistance index (SVRI), pulmonary vascular resistance index (PVRI), alveolo-arterial oxygen difference (A$\left.\mathrm{aDcO}_{2}\right)$, arterio-venous oxygen difference $\left(\mathrm{a}-\mathrm{vDcO}_{2}\right)$, intrapulmonary shunt $(\mathrm{Qs} / \mathrm{Qt} \%)$, oxygen consumption $\left(\mathrm{VO}_{2}\right)$, and $\mathrm{O}_{2}$ delivery $\left(\mathrm{O}_{2}\right.$ Deliv). Body surface area (BSA) was calculated using the formula, BSA $=0.112 \times{ }^{3} V(\text { weight })^{2}(38)$.

Blood samples were obtained at the same time interval for evaluation of blood contact phase, complement systems, and cell count.

Blood gases. $\mathrm{PaO}_{2}, \mathrm{PaCO}_{2}$, and $\mathrm{pH}$ were measured with a blood gas analyzer (Radiometer, BM-S2, Copenhagen, DK).
Hemoglobin levels, $\mathrm{SATaO}_{2}$ and $\mathrm{SATvO}_{2}$ were measured by an oximeter (OSM 2, Hemoximeter, Radiometer). Mixed venous blood samples were collected from the distal portion of the Swan-Ganz catheter.

Sampling procedures and assays. Blood samples were obtained from the proximal lumen of the Swan-Ganz catheter and placed into plastic tubes containing either $3.8 \%$ sodium citrate or EDTA. Plateletpoor plasma was obtained from blood samples centrifuged for $15 \mathrm{~min}$ at $2,500 \mathrm{~g}$. All samples were stored at $-70^{\circ} \mathrm{C}$ until the day of the assay.

Routine coagulation tests were performed using standard methods (39). The coagulant activity of factors XII and XI was measured by a one-stage assay based on the partial thromboplastin time using as substrate factor XII- and XI-deficient plasma (39). Plasma PK levels were measured by the method of Gallimore et al. (40), using S-2302 as substrate and a PK activator (AB Kabi Diagnostica, Stockholm, Sweden); before activation, platelet-poor plasma was incubated with acetone at $0^{\circ} \mathrm{C}$ for $15 \mathrm{~min}$; the activation with $\mathrm{PK}$ activator was maintained for a period of $5 \mathrm{~min}$.

The changes in C1-INH activity and plasma concentration of C1INH antigen were assessed in two additional dogs of each group. Plasma levels of $\mathrm{Cl}$ inhibitor antigen in blood samples were estimated using rocket immunoelectrophoresis (41). Briefly, a 1\% (wt/vol) agarose over gel Bond film with $37.5 \mathrm{mM}$ Tris, $100 \mathrm{mM}$ glycine ( $\mathrm{pH} 8.6$ ) for both gel and electrophoresis buffer, and 3\% human $\mathrm{Cl}$ inhibitor antiserum (Behringwerke, Marburg, FRG). Incubation lasted $12 \mathrm{~h}$ at $10 \mathrm{~V} / \mathrm{cm}$, then it was cooled with tap water. Human $\mathrm{C} 1$ inhibitor was used as reference to estimate the amount of $\mathrm{Cl}$ inhibitor in the experimental blood sample. After electrophoresis, the plates were maintained for $3 \mathrm{~d}$ in a Petri dish with $0.9 \% \mathrm{NaCl}$ to eliminate nonreacting proteins. The endotoxin-treated dog plasma was supplemented with human $\mathrm{Cl}$ inhibitor to increase the precipitin lines against $\mathrm{Cl}$ inhibitor antibodies (42).

The activity of $\mathrm{Cl}-\mathrm{INH}$ was measured by an amidolytic method (kit from Immuno SA Laboratory, Barcelona, Spain) using an excess of $\mathrm{C}_{1}$-esterase and $\mathrm{C}_{2} \mathrm{H}_{5} \mathrm{Co}-\mathrm{Lys}(\mathrm{E}-\mathrm{Cbo})$-Gly-Arg-pNa as substrate.

The fraction $\mathrm{C} 3 \mathrm{c}$ of complement was also determined by electroimmunodiffusion (41), using a dog C3c antiserum (Nordic Immunochemical Laboratory, Tilburg, The Netherlands).

Statistical methods. The results are expressed as the mean $\pm \mathrm{SE}$ of the absolute values and the percent change from baseline. Comparisons between means were made by ANOVA followed by test of Sheffee for multiple comparison. Statistical significance was defined as a $P<0.05$.

\section{Results}

Systemic and pulmonary hemodynamics. Baseline hemodynamic parameters from both groups are presented in Table $\mathbf{I}$.

The percent changes in MAP, PCWP, MPAP, and CVP are summarized in Fig. 1. In both groups, the MAP decreased progressively throughout the experimental period. The decrement in MAP was similar in both groups. In the control group, the MAP decreased from $125 \pm 5$ to $81 \pm 4 \mathrm{~mm} \mathrm{Hg}$ at $180 \mathrm{~min}$, and in the $\mathrm{C} 1-\mathrm{INH}$ group from $129 \pm 6$ to $85 \pm 4 \mathrm{~mm} \mathrm{Hg}$. The fall in MAP occurred despite no change in cardiac filling pressures (CVP and PCWP). In contrast, in both groups, the MPAP remained unchanged during the study period.

Ventricular function. Changes in HR, CI, SI, LVSWI, RVSWI, SVRI, and PVRI are expressed in Table II and Fig. 2. Basal values were similar in both groups (Table I). The CI and SI decreased in both groups while HR remained unchanged. The decline in CI and SI was associated with a concomitant decrease in LVSWI and RVSVI. The degree of decrease in parameters reflecting ventricular function was not the same in both groups. Whereas in the control group CI, LVSWI, and RVSWI decreased progressively throughout the experiment, in 


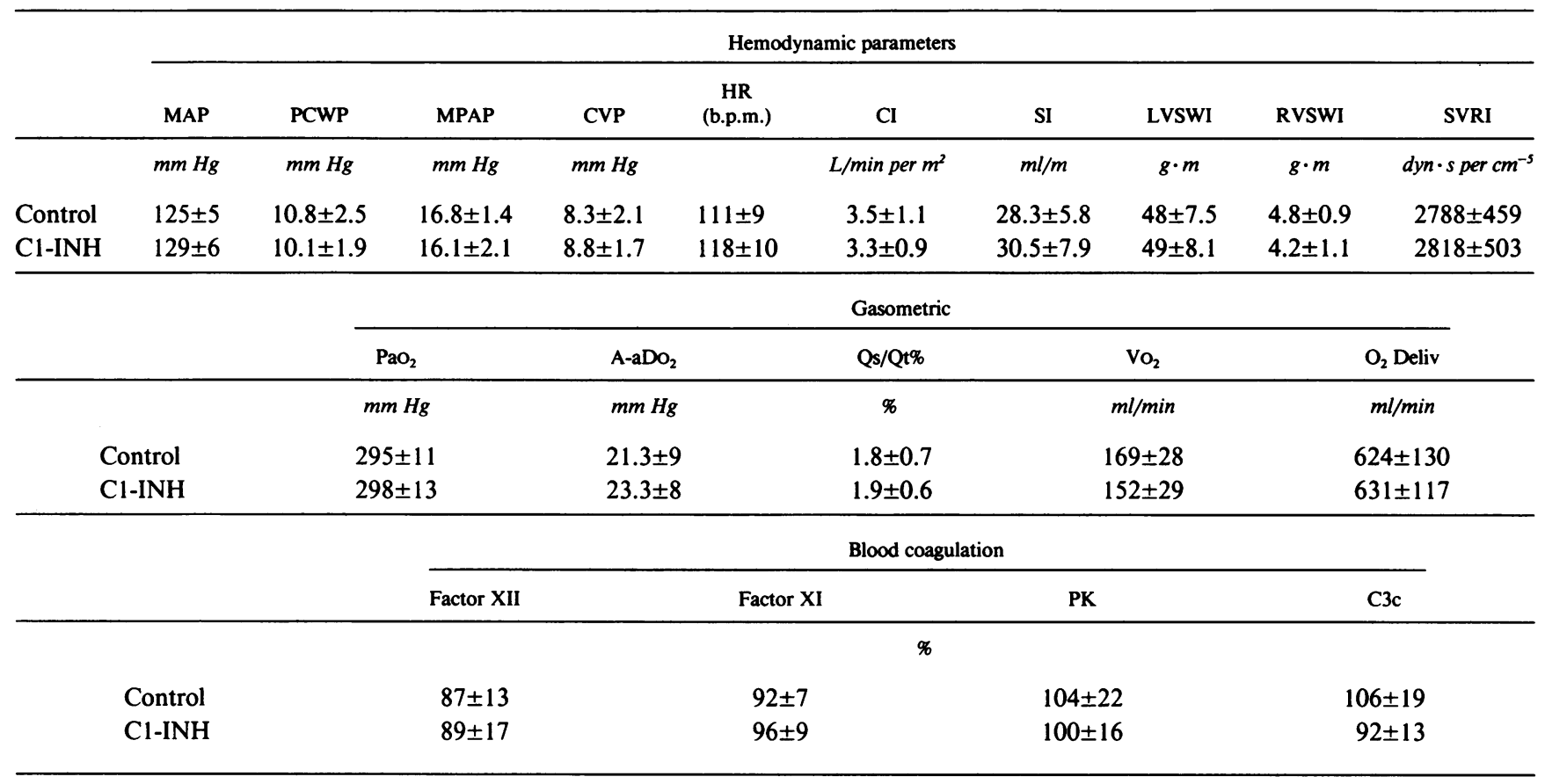

Data are given as means \pm SE.

the $\mathrm{C} 1-\mathrm{INH}$ group these parameters decreased rapidly during the first $60 \mathrm{~min}$ and remained stable until the end of the study period.

The SVRI did not change in either group; the PVRI increased significantly at 120 and $180 \mathrm{~min}$ only in the control group.

Alveolo-capillary gas exchange. In the control group the $\mathrm{PaO}_{2}$ decreased rapidly to $78 \%$ of the basal value during the first $60 \mathrm{~min}$ of the study period, (from $295 \pm 11$ to $230 \pm 23 \mathrm{~mm} \mathrm{Hg}$,
$P<0.001)$. The decline in $\mathrm{PaO}_{2}$ continued until the end of the experiment ( $206 \pm 9 \mathrm{~mm} \mathrm{Hg}, P<0.001$ vs. basal values). As opposed to the control group, no significant change in $\mathrm{PaO}_{2}$ was observed in dogs receiving $\mathrm{Cl}$-INH (Fig. 3). The decrease in $\mathrm{PaO}_{2}$ observed in the control group was associated with an increase in $\mathrm{A}-\mathrm{aDO}{ }_{2}$ and $\mathrm{Qs} / \mathrm{Qt} \%$. No change in these parameters was observed in the $\mathrm{Cl}$-INH group (Fig. 3).

In the control group, both $\mathrm{Vo}_{2}$ and $\mathrm{O}_{2}$ Deliv. decreased significantly at 180 and $120 \mathrm{~min}$, respectively (Table III). This
MAP

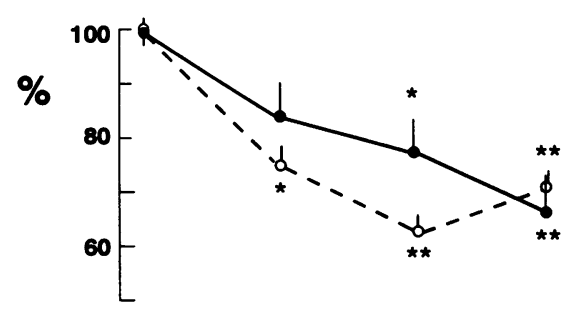

PCWP
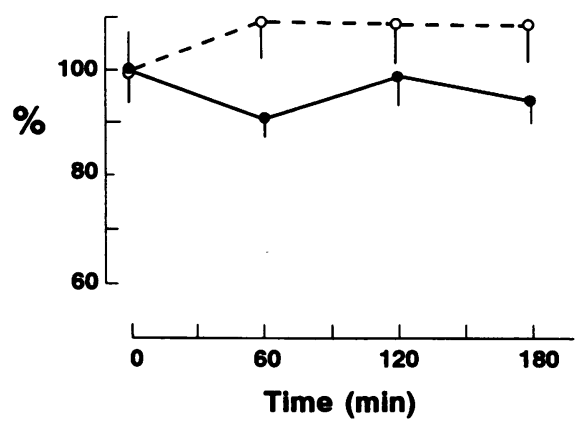

MPAP
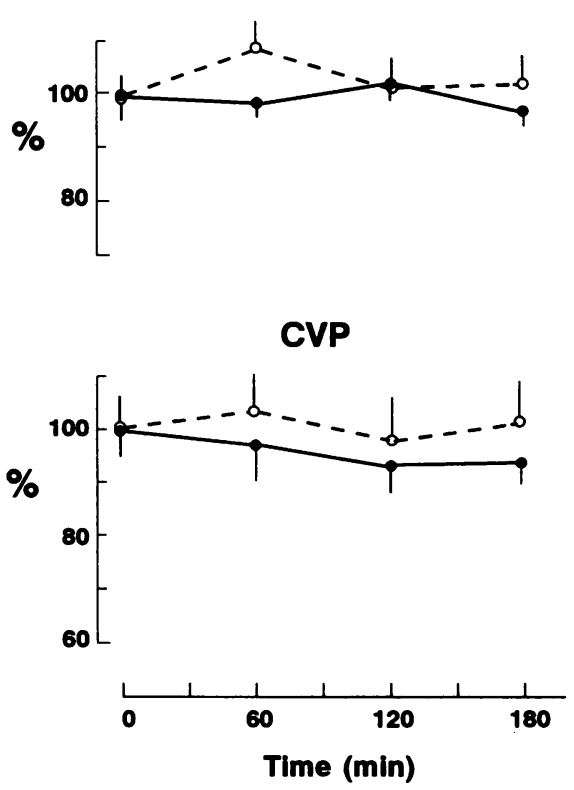

Figure 1. Changes in MAP, MPAP, PCWP, and CVP in two groups of dogs: controls receiving $E$. coli endotoxin $(\bullet)$ and the $\mathrm{Cl}-\mathrm{INH}$ group, which received $\mathrm{Cl}$ esterase inhibitor plus $E$. coli endotoxin (O). The results are expressed as the mean $\pm \mathrm{SE}$ percentage of the basal $(0 \mathrm{~min})$ value. ${ }^{*} P<0.05$ vs. basal; ${ }^{* *} P$ $<0.01$ vs. basal. 

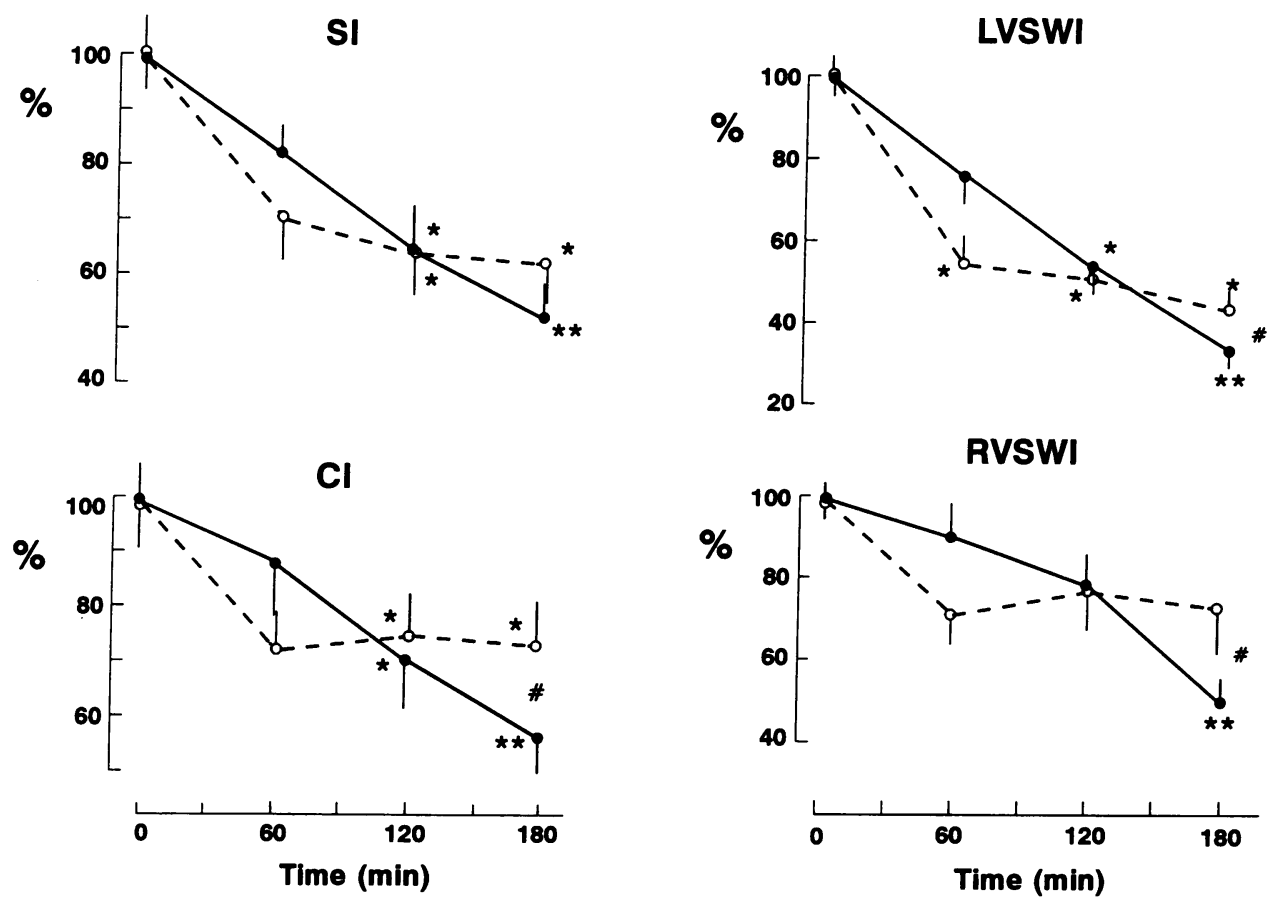

Figure 2. Changes in SI, LVSWI, CI, and RVSWI in two groups of dogs: controls receiving $E$. coli endotoxin $(\bullet)$ and Cl-INH group, which received $\mathrm{Cl}$ esterase inhibitor plus $E$. coli endotoxin (O). The results are expressed as the mean \pm SE percentage of the basal $(0 \mathrm{~min})$ value. ${ }^{*} P$ $<0.05$ vs. basal; ${ }^{* *} P<0.01$ vs. basal; $\# P<0.05$ vs. control.

decrease coincided with the a marked fall in CI. By contrast, no significant change was observed in $\mathrm{VO}_{2}$ and $\mathrm{O}_{2}$ Deliv. in the C1-INH group.

Hematologic parameters. Fig. 4 shows the changes in blood levels of factors XII and XI, PK, and C3c during the study period. The infusion of $E$. coli to the control dogs produced a decrease in blood levels of factors XII and XI. Similar results were observed in the C1-INH group despite the inhibition of the contact system.

In control dogs, the blood levels of PK decreased progressively throughout the study period. The administration of CIINH prevented the fall in PK. A decrease in C3c levels was observed in both groups. However, at $180 \mathrm{~min}$, the decrease in $\mathrm{C} 3 \mathrm{c}$ was more pronounced in control dogs than in those receiving C1-INH. During the $3 \mathrm{~h}$ of the experiment, polymorphonuclear cell count decreased in both groups from $5.5 \pm 0.4 \times 10^{9} /$ liter to $2.8 \pm 0.1 \times 10^{9} /$ liter $(P<0.01)$ in the controls and from $6.8 \pm 0.4 \times 10^{9} /$ liter to $2.3 \pm 0.1 \times 10^{9} /$ liter $(P<0.01)$ in the

Table II. Percent Change in HR, SVRI, and PVRI in Control and C1-INH Groups during the Experimental Period

\begin{tabular}{|c|c|c|c|c|}
\hline & & \multicolumn{3}{|c|}{ Period } \\
\hline & & 60 & 120 & 180 \\
\hline & & & $\min$ & \\
\hline \multirow{2}{*}{ HR } & Control & $106 \pm 03$ & $109 \pm 05$ & $110 \pm 03$ \\
\hline & $\{\mathrm{C} 1-\mathrm{INH}$ & $121 \pm 07$ & $120 \pm 08$ & $121 \pm 08$ \\
\hline \multirow{2}{*}{ SVRI } & CControl & $98 \pm 08$ & $111 \pm 07$ & $125 \pm 07$ \\
\hline & $\{\mathrm{Cl}-\mathrm{INH}$ & $109 \pm 08$ & $92 \pm 07$ & $105 \pm 09$ \\
\hline \multirow{2}{*}{ PVRI } & CControl & $141 \pm 19$ & $205 \pm 21^{*}$ & $220 \pm 18^{*}$ \\
\hline & $\{\mathrm{Cl}$-INH & $143 \pm 14$ & $157 \pm 10$ & $156 \pm 15^{\ddagger}$ \\
\hline
\end{tabular}

${ }^{*} P<0.05$ vs. baseline, ${ }^{\ddagger} P<0.05$ vs. control.
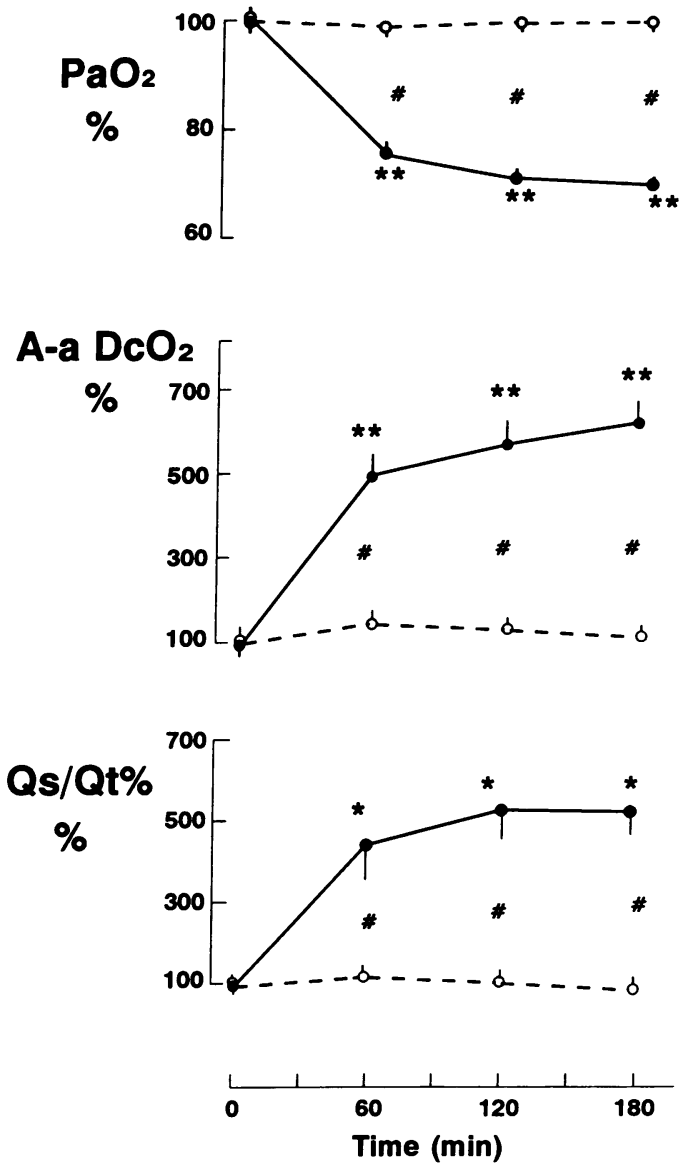

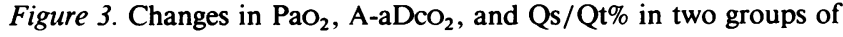
dogs: controls receiving $E$. coli Endotoxin $(\bullet)$ and $C 1$-INH group, which received $\mathrm{Cl}$ esterase inhibitor plus $E$. coli endotoxin $(0)$. The results are expressed as the mean $\pm \mathrm{SE}$ percentage of the basal $(0 \mathrm{~min})$ value. ${ }^{*} P<0.05$ vs. basal; ${ }^{* *} P<0.01$ vs. basal; $\# P<0.05$ vs. control. 
Table III. Mean Percent Change in $\mathrm{VO}_{2}, \mathrm{O}_{2}$-Deliv, and a-vDcO in Control and C1-INH Groups during the Experimental Period

\begin{tabular}{|c|c|c|c|c|}
\hline & & \multicolumn{3}{|c|}{ Period } \\
\hline & & 60 & 120 & 180 \\
\hline & & & $\min$ & \\
\hline \multirow{2}{*}{$\mathrm{Vo}_{2}$} & Control & $99 \pm 7$ & $82 \pm 7$ & $77 \pm 7^{*}$ \\
\hline & $\{\mathrm{Cl}$-INH & $97 \pm 9$ & $104 \pm 8$ & $108 \pm 9^{\ddagger}$ \\
\hline \multirow{2}{*}{$\mathrm{O}_{2}$-Deliv } & Control & $87 \pm 9$ & $69 \pm 7^{*}$ & $56 \pm 14^{*}$ \\
\hline & $\{\mathrm{Cl}$-INH & $72 \pm 8$ & $75 \pm 8$ & $75 \pm 6^{\ddagger}$ \\
\hline \multirow{2}{*}{ a-v Dco 2} & Control & $99 \pm 7$ & $82 \pm 7$ & $77 \pm 8^{*}$ \\
\hline & Cl-INH & $97 \pm 10$ & $104 \pm 12$ & $108 \pm 12$ \\
\hline
\end{tabular}

${ }^{*} P<0.05$ vs. baseline, ${ }^{\ddagger} P<0.05$ vs. control.

C1-INH group. Mean baseline platelets count was $252 \pm 16$ $\times 10^{3} / \mathrm{mm}^{3}$ and $272 \pm 12 \times 10^{3} / \mathrm{mm}^{3}$ in control and $\mathrm{Cl}-\mathrm{INH}$ groups, respectively. Administration of endotoxin with or without $\mathrm{Cl}$-INH did not produce significant changes in platelet count.

Changes in C1-INH activity and plasma levels of C1-INH antigen are presented in Fig. 5. In two control dogs, endotoxin administration produced a moderate decrease in both $\mathrm{C} 1$-INH activity and plasma levels of $\mathrm{Cl}-\mathrm{INH}$ antigen. In two separate dogs, the administration of $\mathrm{Cl}-\mathrm{INH}$ increased the $\mathrm{Cl}-\mathrm{INH}$ activity and the plasma levels of $\mathrm{C} 1-\mathrm{INH}$ antigen.

\section{Discussion}

This study shows that an inhibition of the contact system by administration of $\mathrm{Cl}$-INH prevents the hypoxemia associated with experimentally induced endotoxic shock.

In dogs, the administration of $E$. coli endotoxin with or without C1-INH produced hypodynamic shock. The hypoten- sion was associated with a decrease in CI and SI. This was explained by a decline in LVSWI and RVSWI, which occurred despite no change in cardiac filling pressures. The production of hypodynamic shock suggests a deterioration in cardiac function induced by endotoxin which has been previously described in both animal models and humans (8-12). In both control and $\mathrm{Cl}$-INH groups, this hypodynamic state was associated with an increase in $\mathrm{a}-\mathrm{vDCO}_{2}$ and a decrease in serum bicarbonate (data not shown).

Whereas in control animals the $\mathrm{PaO}_{2}$ decreased, this parameter remained unchanged in dogs receiving $\mathrm{Cl}$-INH. Thus, the inhibition of the contact system prevents to some extent the alteration in pulmonary function induced by $E$. coli endotoxin. The decrease in $\mathrm{PaO}_{2}$ produced by $E$. coli endotoxin administration is likely due to the increase in $\mathrm{A}-\mathrm{aDO}_{2}$ and $\mathrm{Qs} / \mathrm{Qt} \%$ and the decrease in $\mathrm{VO}_{2}$ and $\mathrm{O}_{2}$ Deliv. These results suggest that, in our model, endotoxin administration produced the ventilation/perfusion mismatch described in early phases of ARDS (24). The inhibition of the contact system by administration of C1-INH (Fig. 5) prevented the increase in $\mathrm{A}-\mathrm{aDO}_{2}$ and Qs/ $\mathrm{Qt} \%$, and the decrease in $\mathrm{Vo}_{2}$ and $\mathrm{O}_{2}$-Deliv. These data suggest that the ventilation/perfusion mismatch seen in ARDS is in part due to an activation of contact system. A possible interpretation for the hypoxemia observed in our model is a change in airway function induced by endotoxemia. Owing to the anatomical characteristics of the trachea and the bronchial tree in the dog, differences between dynamic and static thoracopulmonary compliance are difficult to measure; thus, small differences in airway pressure $\left(<2 \mathrm{~cm} \mathrm{H}_{2} \mathrm{O}\right)$ due to endotoxin may have not been detected. Nevertheless, the differences observed in $\mathrm{PaO}_{2}$ between the control and $\mathrm{Cl}-\mathrm{INH}$ groups are more likely attributable to an effect on the alveolocapillary exchange than to a change in airway function.

In our control dogs the alteration in pulmonary function was associated with an activation of the contact system as evidenced by a decrease in PK, factor XII, C1-INH, factor XI, and C3c (Figs. 4 and 5). This decrease could not be attributed to

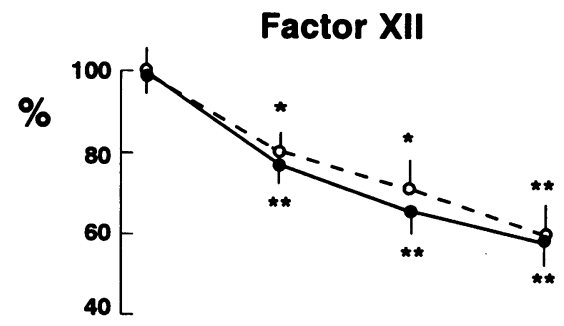

Prekallikrein

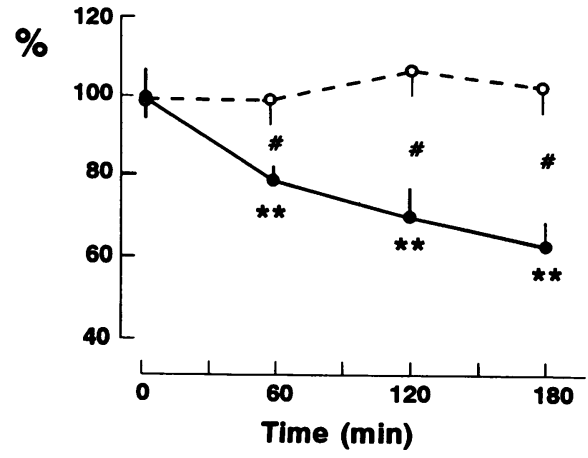

Factor XI
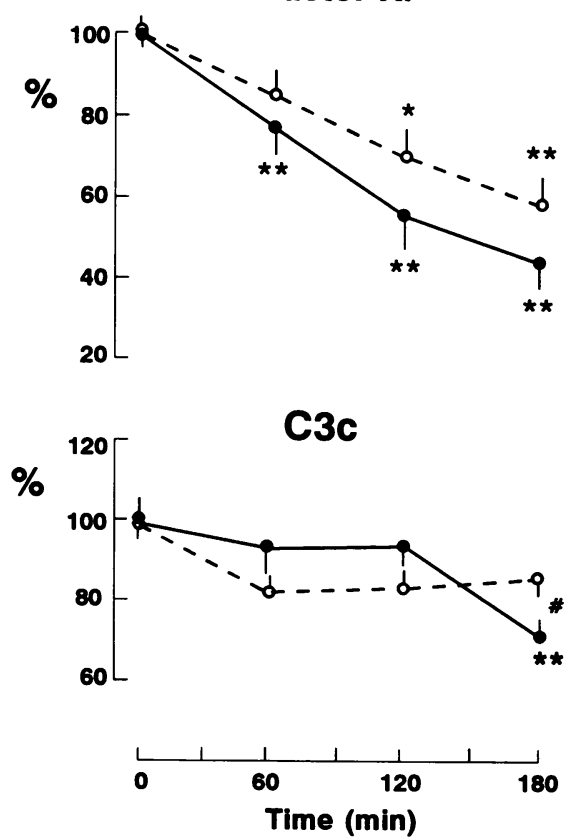

Figure 4. Changes in factors XII and $\mathrm{XI}$, prekallikrein, and fraction $\mathrm{C} 3 \mathrm{c}$ of complement in two groups of dogs: controls receiving $E$. coli endotoxin $(\bullet)$ and C1-INH group, which received $\mathrm{Cl}$ esterase inhibitor plus $E$. coli endotoxin (O). The results are expressed as the mean $\pm \mathrm{SE}$ percentage of the basal $(0 \mathrm{~min})$ value. ${ }^{*} P<0.05$ vs. basal; ${ }^{* *} P$ $<0.01$ vs. basal; $\# P<0.05$ vs. control. 

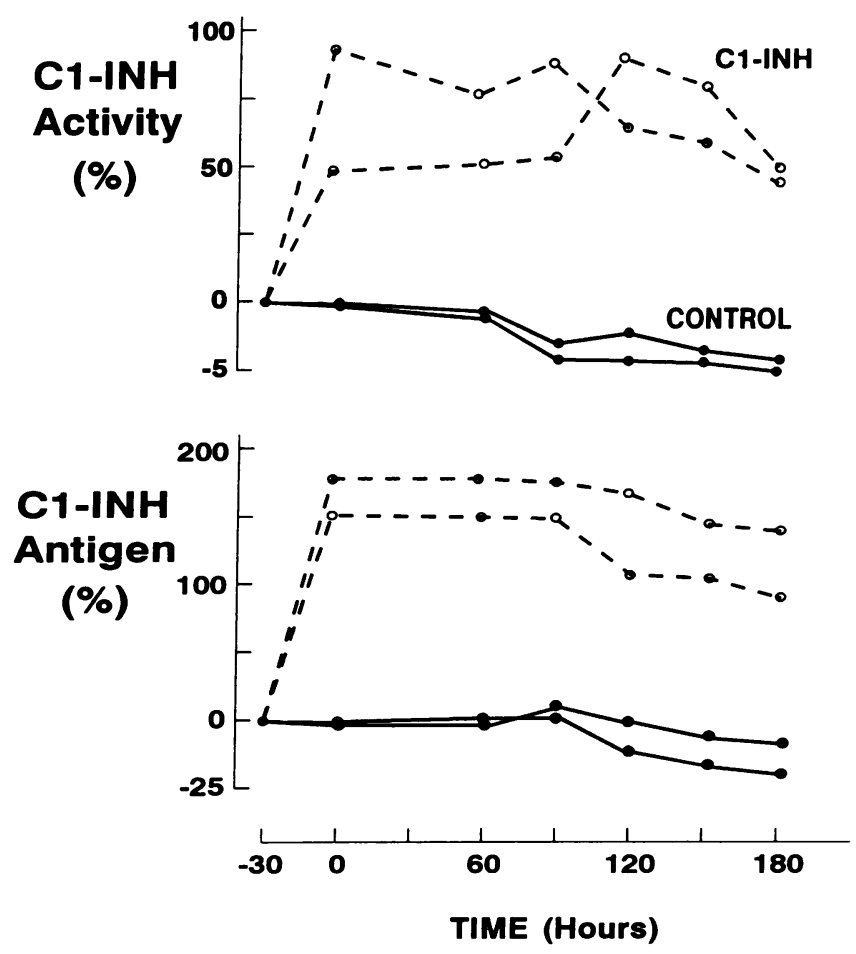

Figure 5. Changes in activity of $\mathrm{Cl}$ esterase inhibitor (C1-INH Activity) and in plasma antigen levels (Cl-INH Antigen) in two control dogs receiving E. coli endotoxin $(\bullet)$ and in two dogs which received $\mathrm{Cl}$ esterase inhibitor plus $E$. coli endotoxin (C1-INH group) (O). Results are expressed as percent change from basal values obtained before the administration of endotoxin and C1-INH.

hemodilution in that the hematocrit increased moderately during the experiment and the increase was similar in both groups (data not shown). Previous studies by us and others have shown that, in ARDS patients, the plasma levels of $\mathrm{HK}$, factor XII, and PK were decreased suggesting an activation of the kallikrein-kinin system $(29,30)$. In our study (29), the decrease in PK levels correlated with the severity of the pulmonary dysfunction; conversely, in patients with pulmonary dysfunction due to cardiogenic pulmonary edema without ARDS, the plasma levels of PK, factor XII, and high molecular weight kininogen were not decreased. Thus, it appears that in ARDS the activation of the contact system is not a direct consequence of the pulmonary edema (31).

Carlson et al. (43) and Mcguire et al. (44) have estimated that the activation of the kallikrein-kinin system is the most important factor leading to ARDS. The study of Colman (45) suggested that during the activation of the blood coagulation system, Hageman factor undergoes contact activation with PK in the presence of a cofactor, high molecular weight kininogen, and a negatively charged surface. This originates in the formation of a serine protease, kallikrein. Subsequently, the high molecular weight kininogen releases bradykinin, the final product of the kallikrein-kinin system activation (46). This vasoactive peptide would induce pulmonary damage resulting in an increase in vascular permeability and interstitial edema (44). An activation of PK would also cause the release of elastase by neutrophils (47). Elastase then can produce tissue damage favoring ARDS. In the present study, the administration of endotoxin produced a significant decrease in number of neutro- phils, however a direct measurement of cell activation is not available.

In addition, endotoxin administration produces an activation of the complement system $(48,49)$; in our dogs, this activation was suggested by the decrease in $\mathrm{C} 3 \mathrm{c}$. Complement activation leads to deposition of terminal complement proteins C5b-9 on platelets and endothelial cells, with subsequent cellular activation and expression of GMP-140 (50, 51). Subsequently, the activation of GMP-140 induces adhesion and activation of neutrophils creating a vicious circle of activation-induced activation (52). The administration of C1-INH may halt this vicious circle by preventing the activation of complement. This has been suggested by previous studies in rabbits (34) and pigs (35).

The PVRI increased significantly in the control group. This has been attributed to multiple hemodynamic changes including the release of vasoactive peptides during endotoxic shock (53). In dogs pretreated with C1-INH, the PVRI did not increase significantly; this may have been the result of the inhibition of the contact system which could have partially prevented endothelial damage. The observed decrease in RVSWI in the control group may be explained by a negative inotropic effect of endotoxin $(11,12)$; in dogs receiving $\mathrm{C} 1$-INH the decrement in RVSWI was not as marked as in controls, a better oxygenation may have ameliorated the negative inotropic effect of endotoxin.

Finally, the worse hemodynamic conditions observed in the control group may be responsible for the decrease in $\mathrm{VO}_{2}$ and in $\mathrm{O}_{2}$-Deliv, resulting in less $\mathrm{O}_{2}$ supply to the tissues.

In summary, the administration of $E$. coli endotoxin induces hypodynamic shock and a decrease in $\mathrm{PaO}_{2}$. This is associated with an increase in PVRI and an activation of the contact system. The inhibition of the contact system by administration of $\mathrm{Cl}$-INH in addition to $E$. coli endotoxin, prevented the decrease in $\mathrm{PaO}_{2}$ and the increase in PVRI. In conclusion, it is likely that hypoxemia induced by endotoxic shock is mediated by an activation of the contact system.

\section{Acknowledgment}

This study was supported by a research grant from "Fundación Reina Sofia-Cajasur."

\section{References}

1. Du Pont, H. L., and W. W. Spink. 1969. Infections due to Gram negative organisms: an analysis of 860 patients with bacteriemia at the University of Minnesota Medical Center. Medicine. 48:307-332.

2. Mc Govan, J. E., M. W. Barnes, and M. Finland. 1975. Bacteriemia at the Boston City Hospital: occurrence and mortality during 12 selected years with special reference to hospital acquired cases. J. Infect. Dis. 132:316-329.

3. Mc Cabe, W. R., and G. G. Jackson. 1962. Gram-negative bacteriemia: clinical, laboratory and therapeutic observations. Arch. Intern. Med. 110:856866.

4. Winslow, E. S., H. S. Loeb, S. H. Rahimtoola, S. Kamath, and R. M. Gunnar. 1973. Hemodynamic studies and results of therapy in 50 patients with bacteriemic shock. Am. J. Med. 54:421-430.

5. Udhoji, V. N., and M. H. Weil. 1965. Hemodynamic and metabolic studies on shock associated with bacteriemia: observation on 16 patients. Ann. Intern. Med. 62:966-978.

6. Kreger, B. E., D. E. Craven, and W. R. McCabe. 1980. Gram-negative bacteriemia. IV. Reevaluation of clinical features and treatment in 612 patients. Am. J. Med. 68:344-355.

7. Fein, A. M., M. Lippmann, H. Holtzman, A. Eliraz, and S. K. Golberg. 1983. The risk factors, incidence, and prognosis of ARDS following septicemia. Chest. 83:40-42.

8. Parker, J. L., and H. R. Adams. 1969. Myocardial effects of endotoxin 
shock: characterization of an isolated heart muscle model. Adv. Shock Res. 163:175-179.

9. Parker, M., J. H. Shelhamer, S. L. Bacharach, M. V. Green, C. Natanson, T. M. Frederick, B. A. Damske, and J. E. Parrillo. 1984. Profound but reversible myocardial depression in patients with septic shock. Ann. Intern. Med. 100:483490.

10. Ellrodt, A. G., M. S. Riedinger, A. Kimchi, D. S. Berman, J. Maddahi, H. J. C. Swan, and G. H. Murata. 1985. Left ventricular performance in septic shock: reversible segmental and global abnormalities. Am. Heart J. 110:402-409.

11. Natanson, C., M. Fink, H. K. Ballantyne, T. J. MacVittie, J. J. Conklin, and J. E. Parrillo. 1986. Gram-negative bacteriemia produces both severe systolic and diastolic cardiac dysfunction in a canine model that simulates human septic shock. J. Clin. Invest. 78:259, 270.

12. Suffredini, A. F., R. E. Fromm, M. M. Parker, M. Brenner, J. A. Kovacs, R. A. Wesley, and J. E. Parrillo. 1989. The cardiovascular response of normal humans to the administration of endotoxin. N. Engl. J. Med. 321:280-287.

13. Mason, J. W., V. Kleeberg, P. Dolan, and R. W. Colman. 1970. Plasma kallikrein and Hageman factors in gram-negative bacteriemia. Ann. Intern. Med. 73:545-551.

14. O'Donnell, T. F., G. H. A. Clowes, and R. C. Talamo. 1976. Kinin activation in the blood of patients with sepsis. Surg. Gynecol. Obstet. 143:539-541.

15. Aasen, A. O., W. Frolich, O. D. Saugstad, and E. Amundsen. 1978. Plasma kallikrein activity and prekallikrein levels during endotoxin shock in dogs. Eur. Surg. Res. 10:50-62.

16. Aasen, A. O., K. Ohlsson, M. Labsbraten, and E. Amundsen. 1978. Changes in plasminogen levels, plasmin activity and activity of antiplasmins during endotoxin shock in dogs. Eur. Surg. Res. 10:63-72.

17. Gans, H., and W. Krivit. 1969. Effects of endotoxins shock on the clotting mechanism of dogs. Ann. Surg. 152:69-76.

18. Nices, A. R., R. P. Forsyth, H. E. Williams, and K. L. Melmon. 1968 Contribution of Kinins to endotoxin shock in unanesthetized Rhesus monkeys. Circ. Res. 22:155-164.

19. Marder, V. I., S. E. Martin, C. W. Francis, and R. W. Colman. 1987 Consumptive thrombohemorragic disorder. In Hemostasis and Thrombosis: Basic Principles and Clinical Practice. 2nd edition. Robert W. Colman, editor. J. B. Lippincott Co., Philadelphia. 975-1015.

20. Morrison, D. C., and R. J. Ulevitch. 1978. The effect of bacterial endotoxins on host mediation system: a review. Am. J. Pathol. 93:526-617.

21. Colucci, M., G. Balconi, R. Lorenzet, A. Pietra, D. Locati, M. B. Donati, and N. Semeraro. 1983. Cultured human endothelial cells generate tissue factor in response to endotoxin. J. Clin. Invest. 71:1893-1896.

22. Colman, R. W. 1989. The role of plasma proteases in septic shock. $N$. Engl. J. Med. 320:1207-1209.

23. Vito, L., R. C. Dennis, R. D. Weisel, and H. B. Hechtman. 1974. Sepsis presenting as acute respiratory insufficiency. Surg. Gynecol. Obstet. 138:896900.

24. Kaplan, R. L., S. A. Sahn, T. L., and Petty. 1979. Incidence and outcome of the respiratory distress syndrome in Gram-negative sepsis. Arch. Intern. Med. 139:867-869.

25. Spencer, H. 1977. Pathology of the Lung, Excluding Pulmonary Tuberculosis. 3rd edition. Pergamon Press, New York. 235-240.

26. Bachofen, A., and E. R. Weibel. 1977. Alterations of the gas exchange apparatus in adult respiratory insufficiency associated with septicemia. Am. Rev Respir. Dis. 116:589-615.

27. Idell, S., K. K. James, E. G. Levin, B. S. Schwartz, N. Manchada, R. J. Maunder, T. R. Martin, J. Mclarty, and D. S. Fair. 1989. Local abnormalities in coagulation and fibrinolitic Pathways predispose to alveolar fibrin deposition in the adult respiratory distress syndrome. J. Clin. Invest. 84:695-705.

28. Bertozzi, P., B. Astedt, L. Zenzius, K. Lynch, F. Le Maire, W. Zapol, and H. Chapman. 1990. Depressed brochoalveolar urokinase activity in patients with adult respiratory distress syndrome. N. Engl. J. Med. 322:890-897.

29. Velasco, F., A. Torres, A. Guerrero, P. Andres, R. Guerrero, P. Aljama, and F. Alvarez. 1986. Behaviour of the contact phase of blood coagulation in the adult respiratory distress syndrome (ARDS). Thromb. Haemostasis. 55:357-60

30. Carvalho, A. C., S. De Marinis, C. F. Scott, L. D. Silver, A. H. Schmaier, and R. W. Colman. 1988. Activation of the contact system of plasma proteolysis in the adult respiratory distress syndrome. J. Lab. Clin. Med. 112:270-277.
31. Herrera, C., F. Velasco, A. Guerrero, R. Guerrero, F. Alvarez, and A. Torres. 1989. Contact phase of blood coagulation in cardiogenic pulmonary oedema (CPO) and adult respiratory distress syndrome (ARDS). Intensive Care Med. 15:99-104.

32. Shapira, M., C. F. Scott, and R. W. Colman. 1982. Contribution of plasma protease inhibitors to the inactivation of kallikrein in plasma. J. Clin. Invest. 69:462-468.

33. Van der Graaf, F., J. A. Koeman, and B. N. Bonma. 1983. Inactivation of Kallikrein in human plasma. J. Clin. Invest. 71:149-158.

34. Tiantaphyllopoulus, D. C., and M. S. Cho. 1986. Effects of injection of Cl inactivator on the platelet count and blood coagulation in rabbits infused with endotoxin. Thromb. Haemostasis. 55:293.

35. Siebeck, M., Philapitsch, A., Wiesinger, H., and H. F. Welter. 1985. The role of C1-Esterase inhibitor during early septicemia. In Proceedings VIIth International Congress of Emergency Surgery, Munich. 140-143.

36. Yang, S. S., L. G. Bentivoglio, V. Maranhao, and H. Goldberg. 1972. From Cardiac Catheterization Data to Hemodynamic Parameters. F. A. Davis Company. New York. 332 pp.

37. Nunn, J. F. 1979. Applied Respiratory Physiology. Butterworth \& Co. Ltd., London. 524 pp.

38. Lacroix, E., and I. Leusen. 1965. La circulation hépatique et splacnique. $J$. Physiol. (Paris). 57:115-122.

39. Caen, J., editor. 1968. Methodes d'exploration et diagnostic practique. In L'Hemostase. Expansion Scientifique Française, Paris 1968:315.

40. Gallimore, M. J., E. Ammundsen, M. Larsbraaten, K. Lyngaas, and E. Faired. 1979. Studies on plasma inhibitors of plasma kallikrein using chromogenic peptide substrate assay. Thromb. Res. 16:695-703.

41. Axelsen, N. H., and E. Bock 1983. Electroimmunoassay (rocket immunoelectrophoresis). Scand. J. Immunol. 17:103-106.

42. Funkhouser, E. A., and C. S. Ramadoss. 1980. Synthesis of nitrite reductase in Chlorella. II. Evidence for synthesis in ammonia grown cells. Plant. Physiol. 65:944-948.

43. Carlson, R. W., R. C. Schaeffer, M. Carpio, and M. H. Weil. 1987. Edema fluid and coagulation changes during fulminant pulmonary edema. Chest. 79:4349.

44. McGuire, W. W., R. G. Spragg, A. B. Cohen, and C. G. Cochrane 1982 Studies on the pathogenesis of the adult respiratory distress syndrome. J. Clin. Invest. 69:543-553.

45. Colman, R. W. 1984. Surface-mediated defense reactions the plasma contact activation system. J. Clin. Invest. 73:1249-1253.

46. Kaplan, A. P. 1978. Initiation of the intrinsic coagulation and fibrinolytic pathways of man: the role of surfaces. Hageman factor prekallikrein, high molecular weight kininogen and factor XI. Prog. Hemostasis Throm. 4:127-175.

47. Wachtfogel, Y. T., U. Kucich, H. L. James, C. F. Scott, M. Schapira, M. Zimmerman, A. B. Cohen, and R. W. Colman. 1983. Human plasma kallikrein releases neutrophil elastase during blood coagulation. J. Clin. Invest. 72:16721677.

48. Craddock, P., J. Fher, M. Brigham, R. Kronenmberg, and J. Jacob. 1977. Complement and leucocyte-mediated pulmonary dysfunction in hemodialysis. N. Engl. J. Med. 296:769-774.

49. Craddock, P., J. Fher, A. Dalmasso, K. Brigham, and H. Jacob. 1977. Hemodialysis leukopenia: pulmonary vascular leukostasis resulting from complemental activation by dialyzer cellophane membrane. J. Clin. Invest. 59:879888.

50. Hattori, R., K. K. Hamilton, R. P. McEver, and P. J. Sims. 1989. Complement proteins $\mathrm{C} 5 \mathrm{~b}-9$ induce secretion of high molecular weight multimers of endothelial von Willebrand factor and translocation of granule membrane protein GMP-140 to the cell surface. J. Biol. Chem. 264:9053-9060.

51. Wiedmer, T., B. Ando, and P. J. Sims. 1987. Complement C5b-9-stimulated platelet secretion is associated with a $\mathrm{Ca}^{2+}$-initiated activation of cellular protein kinases. J. Biol. Chem. 262:13674-13681.

52. Platel, K. D., G. A. Zimmerman, S. M. Prescott, R. P. McEver, and T. M. McIntyre. 1991. Oxygen radicals induce human endothelial cells to express GMP-140 and bind neutrophils. J. Cell Biol. 112:749-759.

53. Zimmerman, G. A., A. H. Morris, and M. Cengiz. 1982. Cardiovascular alterations in the adult respiratory distress syndrome. Am. J. Med. 73:25-34. 